NBER WORKING PAPER SERIES

\title{
VISUAL TOOLS AND NARRATIVES: NEW WAYS TO IMPROVE FINANCIAL LITERACY
}

\author{
Annamaria Lusardi \\ Anya Savikhin Samek \\ Arie Kapteyn \\ Lewis Glinert \\ Angela Hung \\ Aileen Heinberg \\ Working Paper 20229 \\ http://www.nber.org/papers/w20229
NATIONAL BUREAU OF ECONOMIC RESEARCH
1050 Massachusetts Avenue
Cambridge, MA 02138
June 2014

The research reported herein was performed pursuant to a grant from the U.S. Social Security Administration (SSA) funded as part of the Financial Literacy Research Consortium. The authors thank participants at the Financial Literacy Center (FLC) workshops in Cambridge, MA, and Washington, DC, for comments, Tania Gutsche for excellent assistance on navigating the American Life Panel, and Anshuman Didwania and Amanda Chuan for research assistance. This research was funded by the National Institute on Aging under grant 5P01AG008291. The opinions and conclusions expressed herein are solely those of the authors and do not represent the opinions or policy of SSA, the National Bureau of Economic Research, any agency of the Federal Government, or any other institution with which the authors are affiliated.

NBER working papers are circulated for discussion and comment purposes. They have not been peerreviewed or been subject to the review by the NBER Board of Directors that accompanies official NBER publications.

(C) 2014 by Annamaria Lusardi, Anya Savikhin Samek, Arie Kapteyn, Lewis Glinert, Angela Hung, and Aileen Heinberg. All rights reserved. Short sections of text, not to exceed two paragraphs, may be quoted without explicit permission provided that full credit, including $\odot$ notice, is given to the source. 
Visual Tools and Narratives: New Ways to Improve Financial Literacy

Annamaria Lusardi, Anya Savikhin Samek, Arie Kapteyn, Lewis Glinert, Angela Hung, and Aileen Heinberg

NBER Working Paper No. 20229

June 2014

JEL No. D14,D91

\begin{abstract}
We developed and experimentally evaluated four novel educational programs delivered online: an informational brochure, a visual interactive tool, a written narrative, and a video narrative. The programs were designed to inform people about risk diversification, an essential concept for financial decisionmaking. The effectiveness of these programs was evaluated using the RAND American Life Panel. Participants were exposed to one of the programs, and then asked to answer questions measuring financial literacy and self-efficacy. All of the programs were found to be effective at increasing self-efficacy, and several improved financial literacy, providing new evidence for the value of programs designed to help individuals make financial decisions. The video was more effective at improving financial literacy scores than the written narrative, highlighting the power of online media in financial education.
\end{abstract}

Annamaria Lusardi

The George Washington University

School of Business

2201 G Street, NW

Duques Hall, Suite 450E

Washington, DC 20052

and NBER

alusardi@gwu.edu

Anya Savikhin Samek

University of Wisconsin, Madison

1300 Linden Drive

Madison, WI 53706

anyasamek@gmail.com

Arie Kapteyn

University of Southern California

12015 Waterfront Drive

Playa Vista, CA 90094-2536

and NBER

kapteyn@usc.edu
Lewis Glinert

Department of Asian \& Middle Eastern Languages and Literatures

Dartmouth College

Hanover, NH 03755

Lewis.Glinert@Dartmouth.edu

Angela Hung

RAND Corporation

1776 Main Street

Santa Monica, CA 90407

ahung@rand.org

Aileen Heinberg

Independent consultant

3025 South Court

Palo Alto, CA 94306

aheinberg@gmail.com 


\section{Introduction}

Over the past thirty years, individuals have had to become increasingly responsible for their own financial security after retirement. Prior to the 1980s, many Americans relied mainly on Social Security and employer-sponsored defined benefit (DB) pension plans. Today, by contrast, individuals are increasingly turning to defined contribution (DC) plans and Individual Retirement Accounts (IRAs) to help finance their retirement years. The transition to the DC retirement saving model has the advantage of permitting more worker flexibility and labor mobility than in the past, yet it imposes on workers a greater responsibility to plan, save, invest, and decumulate retirement wealth sensibly. Thus, retirement security will depend more and more on individuals' saving and planning decisions.

Unfortunately, studies show that few individuals plan for retirement, and fewer develop and follow through on a financial plan for retirement (Lusardi and Mitchell, 2007a, 2008, 2009, 2011a,b). Financial literacy, and specifically the knowledge of financial concepts that are the basis for financial decision-making, is one important predictor of retirement planning, not just in the US but also worldwide (Lusardi and Mitchell, 2011c). In addition to knowledge of interest compounding and inflation, risk diversification has been singled out as a concept that is critically important for retirement planning and for several other financial decisions (Lusardi and Mitchell, 2011a,b,c, 2014; Lusardi and De Bassa Scheresberg, 2013). Self-efficacy with regard to financial decisionmaking also plays a role in the likelihood that an individual will follow through with retirement planning (Gutter, Copur, and Garrison, 2009; Shockey and Seiling, 2004). As employers move to give employees more responsibility for their own financial security in 
retirement, ensuring that workers are well equipped to make financial decisions becomes increasingly important.

Given the pressing need to improve financial literacy among individuals, financial education programs have become an important topic of research (Bernheim, Garrett, and Maki, 2001; Bernheim and Garrett, 2003; Lusardi and Mitchell 2007b, 2014; Atkinson, 2008). While findings are still mixed, there is emerging evidence that financial education can be made effective (Lusardi and Mitchell, 2014). However, recruiting individuals into educational seminars is a difficult task, and educational programs often require full-time instructors or counselors. This makes seminars costly and hence difficult to scale up. Research also finds that those consumers who need help the most are the least likely to seek various types of counseling (Meier and Sprenger, 2013).

The recent connectivity of most households to the Web provides an opportunity to develop and bring new educational materials to users quickly and efficiently. Moreover, interventions delivered via the Web could be successful in attracting users due to ease of accessibility and low time commitment requirements. In this paper, we focus on the development and evaluation of new web-based educational programs aimed at explaining the concept of risk diversification. Understanding risk diversification is fundamental both to optimally allocating wealth and to retirement planning, yet most individuals do not have a solid grasp of the concept. In fact, when responding to a battery of questions measuring financial literacy, the majority of individuals fare particularly poorly on questions related to risk and risk diversification (e.g., Lusardi and Mitchell, 2009, 2011a,b,c, 2014; Lusardi, Mitchell, and Curto, 2012; van Rooij, Lusardi, and Alessie, 2011, 2012). 
We designed four different educational programs for delivery online: an informational brochure, an interactive visual tool, a written narrative, and a video narrative. All of these programs are designed to improve knowledge of risk diversification but differ substantially from any previous financial education programs both because they make use of extensive research on financial literacy and for the innovative ways in which they communicate the information.

We evaluated the effectiveness of the educational programs that we developed using a representative sample of individuals age 20+ from the RAND American Life Panel (ALP). ${ }^{1}$ Eight hundred ninety-two (892) ALP participants were randomized to receive one of the four programs or were assigned to a control group. After being exposed to the program, participants completed short questionnaires aimed at evaluating their knowledge of basic financial concepts related to risk diversification, confidence in their financial literacy, and self-efficacy. The programs were designed to appeal to young adults, but were evaluated for use by young and older adults.

Our main results are as follows: (1) videos were most effective at improving financial literacy scores and increasing levels of confidence in financial knowledge; (2) the visual tool increased confidence in financial knowledge, but did not appear to have an effect on financial literacy scores; (3) participants who were exposed to a video had significantly higher financial literacy scores than those who were exposed to a written narrative; and (4) all of the treatments were effective at increasing self-efficacy. Overall our results provide new evidence for the value of online programs as new ways to improve financial literacy.

\footnotetext{
${ }^{1}$ https://mmicdata.rand.org/alp/
} 
This paper makes three main contributions to the existing literature on financial literacy and financial education. First, we show that interventions, even short-duration ones, can help improve financial literacy, a finding that speaks to the widespread lack of financial knowledge in the population. Second, interactive programs, such as videos and visual tools, can be particularly effective in educating individuals about complex concepts such as risk diversification, a finding consistent with the burgeoning interest in games and similar tools designed to improve financial literacy. Third, not just financial literacy but also confidence and self-efficacy can be affected by relatively short-duration interventions, a finding that can be particularly important for some demographic groups, such as women.

\section{Narratives and Visual Tools}

The narratives and visual tools that we developed are grounded in evidence-based research. For example, in the social sciences, narratives have been established as a method that is effective for creating cognitive involvement and affecting comprehension and behavior change. In the field of visual analytics, visual tools have been established as a way to shift information processing to the human perceptual system and nudge behavior. However, the use of narratives and visuals (interactive or not) in the financial literacy domain has remained relatively under-explored. We explain each method in turn.

\subsection{Narratives}

Narratives are an established method of creating cognitive involvement and emotional immersion, changing minds, and generating a desire to change course (Bruner, 1987). Narratives are widely adopted in adult education with demonstrated effects on 
motivation, comprehension, and recall (Norris, Guilbert, Smith, Hakimelahi, and Phillips, 2005; Davidhizar and Lonser, 2003). Narratives have also been used to improve health literacy and health-related behavior change (Michielutte, Bahnson, Dignan, and Schroeder, 1992; Petraglia, 2007; Corby, Enguídanos, and Kay, 1996) and findings suggest that public perceptions of risk may be shaped more by narratives than by calculations (Mairal, 2008). While still underused in the area of financial literacy, narratives could prove to be a natural extension from the health field and well suited to overcoming the mix of disinterest, anxiety, and non-comprehension associated with financial issues. In another paper, we use videos to explain basic financial literacy concepts and show that they affect both knowledge and behavior (Heinberg, Hung, Kapteyn, Lusardi, Samek, and Yoong, 2014).

We made use of our team's expertise in financial literacy, marketing, and linguistics to create narratives that are powerful both in terms of comprehension and communication. ${ }^{2}$ The narratives that we developed were delivered in the format of either a written story or a video in which actors performed the story. Thus, we were able to evaluate the effectiveness of both the concept and the mode of delivery. In comparing the written and video medium, we respected the stylistic and narrative norms of the genres, giving the reader/viewer the kind of contemporary written anecdote and short (threeminute) online video to which they may be accustomed. The narrative involved people engaged in a familiar activity (packing to move) and discussing a financial issue of personal relevance: what to do with a major monetary gift (see Appendix A for the script). The story was used to describe and explain risk diversification.

${ }^{2}$ Our project combines the expertise of financial literacy economists, behavioral economists, visual analytics experts, psychologists, and linguists. 


\subsection{Visual tools}

Individuals often struggle with processing information that requires extensive calculations - this type of processing requires a high level of numeracy, which many individuals do not have (Lusardi, 2012). Graphical representations may be an ideal approach for overcoming this problem because they shift information processing to the perceptual system, improving understanding of the concept presented and allowing decision-makers to quickly learn from trends and patterns in the data (Lurie and Mason, 2007). Related work has found that interactive visual presentations (or visual analytic tools) encourage exploration of the decision space and reduce search effort (Rudolph, Savikhin, and Ebert, 2009; Savikhin, Lam, Fisher, and Ebert, 2011; Savikhin, 2012).

One of our goals in this project is to compare the effectiveness of information presented in an interactive format with the effectiveness of the same information delivered in a traditional way, for example via a brochure. Consequently, we developed a two-page brochure and an interactive visual tool that displayed the same information about risk diversification in a portfolio setting. Both were aimed at clarifying the relationship between risk and return and explaining how investing in many assets can reduce risk. The visual tool allowed interactivity and therefore supported reasoning about data through "what if" analysis (i.e., analysis based on key visual analytics concepts—see Keim et al., 2008; Thomas and Cook, 2005). The brochure was made available online; but in practice, the brochure is in a format that could be printed out and handed to participants. However, by posting it online we can directly compare it to the visual tool.

The visual tool that we developed, FinVis (see Figure 1), is a self-contained educational program that assists the user with understanding key concepts about risk and risk diversification and imparts actionable knowledge. This interactive tool has four main 
components: (1) an introduction that describes the way the tool should be used, (2) a tutorial that introduces risk diversification and demonstrates the concept visually, (3) an interactive feature that allows the user to explore the tool and make his/her own choices, and (4) an outcome screen that displays feedback to the user about whether the choices made were relatively more or less risky and whether the user successfully diversified a hypothetical portfolio (see Appendix B). Both the tool and brochure use the same visual representation, i.e., a cone that shows the range of outcomes, as this was found to be an effective way to communicate risk in prior laboratory studies (Rudolph, Savikhin, and Ebert, 2009) and is similar to the representation of risk in a recent related paper (Kaufmann, Weber, and Haisley, 2013).

\subsection{Confidence and Self-Efficacy}

The programs we developed may also have an effect on increasing levels of confidence and self-efficacy surrounding financial decisions. According to Bandura's (1989) social cognitive theory, self-efficacy expectations influence behavior change. Self-efficacy is the belief in one's own ability to perform successfully in a particular situation. For example, an individual's belief that he/she will be able to diversify his/her portfolio is a self-efficacy expectation. Social cognitive theory predicts that self-efficacy helps induce changes in financial behavior. In fact, related work has established a link between educational programs that increase self-efficacy and improved financial decision-making (Shockey and Seiling, 2004). In addition, self-efficacy and confidence have been associated with improved decision-making in the health domain (Holden, 1991).

Social cognitive theory describes several methods of strengthening self-efficacy. Vicarious experience is one of the most important methods and consists of observing the 
behavior of others. Presenting narratives or videos that describe behaviors of other individuals should bolster self-efficacy. In fact, previous work has used video-based rather than live modeling to improve self-efficacy (Gist, 1989). Additional psychological and social marketing research indicates that narratives of a variety of formats can inspire behavior change. Previous research has found that narratives can be effective in generating behavior change and improving motivation through self-efficacy, especially in the health domain. Moreover, keeping information content constant, presenting narrative financial education materials in the format of videos rather than written stories may also significantly impact self-efficacy (Heinberg et al. 2014).

According to social cognitive theory, a second method for improving self-efficacy is mastery experience (Bandura, 1989). Mastery experience involves the help of a trained professional who facilitates completion of step-by-step goals. The creation of the FinVis tool was an effort to recreate an environment where the user can engage in the task and meet goals in a short time frame. The tool acts as the "expert," guiding the user through the process of diversifying a portfolio. While using visual tools to provide mastery experience is relatively new in this domain, we believe it has the potential to increase the effectiveness of the program. Visual analytic tools have been found to increase confidence in financial portfolio selection tasks performed in a laboratory (Savikhin et al., 2011). Our measures allow us to determine whether our interventions affect confidence in knowledge and self-efficacy (where self-efficacy is confidence in one's abilities to diversify a portfolio).

\section{Evaluation}


To evaluate the impact of the programs on knowledge, confidence, and self-efficacy, we designed a randomized experiment using the ALP. The ALP is a representative panel composed of approximately 6,000 US households who are regularly interviewed over the Internet (information on ALP sampling is provided in Appendix C). Data routinely collected in the ALP include a wide array of demographic and economic characteristics. The experiment was fielded from June to September 2012.

Eight hundred and ninety-two (892) ALP participants were included in the evaluation. ${ }^{3}$ Participants were randomized into one of the four treatment groups or into the control group, with at least 100 participants in each treatment cell (see Table 1). Participants randomized into the control group did not receive any treatment. Participants randomized into treatment received one of four educational programs - (i) a video, (ii) a written narrative, (iii) a brochure, (iv) an interactive visual tool—and then were asked to answer a set of questions, like the control group. The experimental design allows us to compare each treatment group with the control group, providing a rigorous measure of the effectiveness of each program on the basis of knowledge, confidence, and selfefficacy. Moreover, we can compare the value of added interactivity and engagement by comparing the treatment group exposed to the visual tool to the treatment group exposed to the brochure and the treatment group exposed to the video to the treatment group exposed to the written narrative. The first row of Table 1 shows the total number of participants by treatment, while the third row shows the number of participants who were able to access the programs (accessibility is discussed in greater detail in the next section.)

\section{[TABLE 1 ABOUT HERE]}

\footnotetext{
${ }^{3}$ All but six people completed the entire evaluation, including exposure to the program and responding to the questionnaire at the end.
} 
The questionnaire that we developed consisted of five short, multiple-choice questions, with one question focused on self-efficacy specific to risk diversification (Q1)

three questions focused on knowledge of risk diversification (Q2-Q4), and one question focused on confidence in the knowledge of risk diversification (Q5). The precise wording of the questions is below:

1. If I need to make an investment decision, I can select a mix of investments that are in line with how much risk I want to take on.
a. Not at all true
b. Hardly true
c. Moderately true
d. Exactly true

2. In general, investments that are riskier tend to provide higher returns over time than investments with less risk.
a. True
b. False
c. Don’t know

3. Which of the following is an accurate statement about investment returns?
a. Usually, investing $\$ 5,000$ in shares of a single company is safer than investing $\$ 5,000$ in a fund which invests in shares of many companies in different industries
b. Usually, investing $\$ 5,000$ in shares of a single company is less safe than investing $\$ 5,000$ in a fund which invests in shares of many companies in different industries
c. Usually, investing $\$ 5,000$ in shares of a single company is equally as safe as investing $\$ 5,000$ in a fund which invests in shares of many companies in different industries.
d. Don't know

4. Suppose you are a member of a stock investment club. This year, the club has about $\$ 200,000$ to invest in stocks and the members prefer not to take a lot of risk. Which of the following strategies would you recommend to your fellow members?
a. Put all of the money in one stock
b. Put all of the money in two stocks
c. Put all of the money in a stock index fund that tracks the behavior of 500 large firms in the United States
d. Don't know

5. How confident are you that you have a grasp of how risk changes when choosing a different mix of investments?
a. Extremely confident
b. Very confident 
c. Somewhat confident

d. Not very confident

e. Not at all confident

Our working assumption is that financial literacy, confidence, and self-efficacy are all relevant for behavior and are important components of financial capability. While financial literacy provides a basic tool for decision-making, confidence and self-efficacy can proxy for the likelihood of taking action based on the (actual or newly acquired) knowledge of the individual.

\section{Summary of Results}

Table 2 provides a summary of the characteristics of participants. We can correlate participant responses with demographic information, including age, gender, race and ethnicity, family income, educational attainment, and number of members in the household. The sample is about $80 \%$ Caucasian, 11\% African-American, and $15 \%$ Hispanic. The average highest educational attainment level of this sample is "some college, no degree" (bracketed) and the average household income is $\$ 40,000-\$ 49,999$ (bracketed). About 55-65\% of respondents are female. The minimum age of participants is 18 , while the average age is 49.5 with a standard deviation of 16 .

\section{[ TABLE 2 ABOUT HERE ]}

We should note that participants needed certain updates to their computers in order to view the videos or use the visual tool, and it is possible that some participants chose to skip these programs due to slow download speeds. After we received comments from early respondents about difficulty with accessing the tools, videos, and brochures, we added a question to the survey asking whether the respondent was able to see the tool, 
video, or brochure. ${ }^{4}$ Approximately $81 \%$ of asked respondents were able to view the brochure, $76 \%$ were able to view the videos, and $65 \%$ were able to use the visual tool. Consequently, in the analysis that follows, we provide measures of the effect on the subsample that was "treated" (those who actually accessed the programs), of the "intentto-treat" effect (all respondents in the treatment conditions, disregarding access), and of the "treatment-on-treated" effect. In order to measure the "treatment-on-treated" effect, which controls for selection bias in subjects' abilities to view the programs, we used instrumental variables (IV) regressions where randomly assigned treatment status is used to instrument for participation (Angrist and Pischke, 2008).

In the analysis of results that follows, sections 4.1 and 4.2 provide results based on t-tests and Chi squared tests. Section 4.3 uses regressions and demographic controls as a robustness check and introduces the "treatment on treated" IV estimates.

\subsection{Financial Literacy}

\subsubsection{Overall Knowledge}

We turn first to the questions measuring knowledge of risk and risk diversification, our questions Q2-Q4. While Q2 and Q3 are knowledge questions, Q4 was designed to test hypothetical decision-making ability. Overall, the proportion of correct answers across the three questions was 71\% among the control group and between $73 \%$ and $80 \%$ among the treatment groups (see Table 3). Columns 1 and 2 of Table 5 present results from ordinary least squares (OLS) regressions in which the dependent variable is the proportion of correct responses to Q2-Q4. These regressions

\footnotetext{
${ }^{4}$ Because the question was added after the survey began, only $50-97 \%$ of respondents, depending on condition, received the question.
} 
use the full sample, not controlling for whether subjects accessed the program. The proportion of correct responses is higher by 8-10 percentage points for all participants randomized to the video treatment, and this result is statistically significant (Columns 12). In addition, when including demographic controls (Column 2), we also see a positive and significant effect not only for the video but also for the brochure (increase of 8 percentage points).

Result 1: When controlling for demographic characteristics, exposing individuals to a video or a brochure that explains risk diversification improves their financial literacy relative to the control group.

\section{[TABLE 3, 5 ABOUT HERE]}

\subsection{2 “Don't Know” Responses}

Each of the questions listed several responses (one of which was correct) that the participant was asked to choose from, including "don't know." Choosing the "don't know" option may indicate lack of confidence or lack of knowledge. Columns 3-4 of Table 5 present OLS regression results in which the dependent variable is the proportion of "don't know" responses. Both the video and the brochure decrease the proportion of "don't know" responses by almost 10 percentage points relative to the control group, a finding that becomes even stronger when we control for demographic characteristics. The visual tool also decreases the proportion of "don't know" responses relative to the control group, though this effect is smaller in magnitude and only significant at the $10 \%$ level when we control for demographic characteristics.

Result 2: The video, brochure, and visual tool all decrease the likelihood of answering “don't know” to financial literacy questions.

${ }^{5}$ For a discussion of the importance of "do not know" answers, see Lusardi and Mitchell (2011a,b,c; 2014). 
The regressions also allow us to compare the video with the written narrative to assess which is the more effective method of improving financial literacy. In the OLS regressions where we control for a set of demographic characteristics, we find a much larger improvement in financial literacy (as measured by the number of correct responses or the number of "do not know" answers) when exposing individuals to a video rather than a written narrative.

Result 3: The video is significantly better than the written narrative at improving the proportion of correct answers and reducing the rate of "don't know" responses.

\subsection{Confidence and Self-Efficacy}

Confidence and self-efficacy are measured using responses to Q5 and Q1, respectively. On average, confidence in the control group is $2.77-2.84$ (between not very confident and somewhat confident) while confidence in the treatment groups is 2.98-3.42 (between somewhat confident and very confident) (see Table 4). Table 5 (columns 5-6) presents OLS regression results in which the dependent variable is confidence in financial knowledge. The video and brochure significantly improved confidence compared to the control group. When we control for demographic characteristics, we find that all treatments significantly improved confidence compared to the control group.

Result 4: All treatments significantly improve confidence in financial knowledge relative to the control group.

\section{[ TABLE 4 ABOUT HERE]}

Turning to self-efficacy, we find that self-efficacy levels in the control group are 2.98 on average (between hardly true and moderately true) while self-efficacy levels in the treatment groups are 3.33-3.41 on average (between moderately true and exactly 
true). While $50 \%$ of respondents in the treatment groups respond exactly true to the selfefficacy question, only $26 \%$ of the control group does so. Columns $7-8$ of Table 5

present OLS regression results in which the dependent variable is level of self-efficacy, as measured in Q1. All treatments significantly improved self-efficacy compared to the control group.

Result 5: All treatments (video, narrative, visual tool, and brochure) significantly improve self-efficacy levels relative to the control group.

Our results also provide some indication that answers to the financial literacy questions are related to levels of confidence and self-efficacy. Using a Spearman rank correlation test, we find a significant and negative relationship between incidence of “don't know" responses and reported levels of confidence in knowledge (Spearman coefficient, $-0.46, p$-value $<0.01$ ) and level of self-efficacy (Spearman coefficient, -0.38 , $p$-value $<0.01)$. Likewise, correct responses to the financial literacy questions are significantly and positively correlated with both confidence in knowledge (Spearman coefficient, 0.43, p-value $<0.01$ ) and self-efficacy (Spearman coefficient 0.29, p-value $<0.01)^{6}$

We can also look at mismatches between knowledge and levels of confidence and self-efficacy, which could be considered a measure of overconfidence. For example, we count the number of participants who do not provide correct responses to the financial literacy questions, yet report that they are confident in the subject matter. We classify a subject who responds very confident or extremely confident in Q5, but actually provides at least one incorrect response in Q2, Q3, or Q4 as "overconfident." Out of 413

\footnotetext{
${ }^{6}$ These coefficients are also statistically significant when evaluating correlations separately by treatment for all cases (i.e., correlating "don't know" and self-efficacy within written narrative, visual tool, brochure, and video separately).
} 
participants who answered at least one question incorrectly, 57 (13.8\%) can be labeled as overconfident using this measure. Overconfidence levels are $11.4 \%$ in the control group, $20 \%$ in the video group, $9.1 \%$ in the written narrative group, $12.3 \%$ in the brochure group, and $23.0 \%$ in the visual tool group. The visual tool appears to significantly increase overconfidence relative to control when using this measure (Wilcoxon rank-sum $p$-value $<0.05)$. Wilcoxon rank-sum tests do not indicate significant differences in overconfidence relative to control for the other treatments. ${ }^{7}$

We also observe several effects of demographic characteristics on knowledge that are reflective of general findings in the literature (e.g., Hung et al., 2009; Lusardi and Mitchell, 2011b, 2014; Bucher-Koenen, Lusardi, Alessie, and van Rooij, 2012). First, women tend to have a lower number of correct responses, more incidences of "don't know" responses, and lower confidence than men. Second, we tend to see negative effects on correct answers and self-efficacy and positive effects on "don't know" responses for African American and Hispanic respondents relative to Caucasian counterparts. Third, age seems to be positively correlated with correct responses and negatively correlated with the proportion of "don't know" responses—older adults are, at baseline, more knowledgeable and more confident—in line with related work finding lower financial literacy of younger adults (Lusardi, Mitchell, and Curto, 2010; Yoong, 2011). Fourth, higher household income is associated with more correct responses on financial literacy questions and higher self-efficacy measures. Finally, educational attainment is positively correlated with correct answers, confidence, and self-efficacy and negatively correlated with the proportion of "don't know" responses. These findings confirm results from other studies and can speak to the quality of our data.

\footnotetext{
${ }^{7} \mathrm{~A}$ t-test finds that overconfidence in the video treatment is higher than overconfidence in the control group ( $\mathrm{t}=-1.5315, \mathrm{p}=0.0635)$. However the Wilcoxon rank-sum test finds this difference to be insignificant $(\mathrm{z}=-1.527, \mathrm{p}=0.1268)$.
} 


\subsection{Treatment on Treated Estimation-Instrumental Variables Regression}

Table 6 provides the instrumental variables (IV) regressions using treatment assignment as an instrument ("treatment on treated" effects). In columns 1 and 2 in Table 6, we see that the video treatment significantly increases the proportion of correct responses (by 11-13 percentage points). The brochure and written narrative treatments also increase the proportion of correct responses when demographic controls are included (significant for brochure and marginally significant for written narrative), while the visual tool does not show any significant effects on the proportion of correct responses. Possible reasons for the lack of effectiveness of the visual tool is the small proportion of people able to view the tool, as well as the small sample size in general (53 respondents report that they could view the tool, which constitutes $65 \%$ of the proportion of people $(64 \%)$ who are asked. In any case, both OLS and IV estimates point to similar findings for the effectiveness of the video and brochure.

Columns 5 and 6 in Table 6 provide IV regressions on confidence in knowledge. In this case, the IV estimates support the finding that confidence is increased in the video and visual tool treatments. The written narrative and brochure treatments have significant positive effects on confidence but only when demographic controls are included. Columns 7 and 8 provide IV regressions on self-efficacy. All of the treatments continue to display positive and significant effects on self-efficacy, with the highest coefficient estimates for the visual tool treatment.

Chow tests comparing the written narrative to the video and the brochure to the visual tool reveal some differential effects between interactive and static treatments. The effect of the video was significantly different from the effect of the written narrative on 
the proportion of correct responses $(\mathrm{F}(1,871)=3.87, \mathrm{p}<0.05)$, the proportion of "don't know" answers $(F(1,876)=4.80, p<0.05)$, and on self-efficacy $(F(1,862)=4.03, p<$ 0.05). The brochure and visual tool did not differentially impact the proportion of correct responses, the proportion of "don't know" answers, or self-efficacy. However, the visual tool was slightly more effective in improving confidence $(F(1,860)=3.76, p<0.10)$.

\section{[TABLE 6 ABOUT HERE]}

\section{Discussion and Conclusion}

We conducted a study on the ALP, a panel representative of the US population, assigning participants to different types of educational programs (i.e., exposing them to a video, a written narrative, a brochure, and a visual tool) and measuring their effects with a set of questions designed to measure financial literacy, self-efficacy, and confidence in the area of risk diversification. Our video and interactive tools are innovative in that they engage the viewer and provide an easy and enhanced way of communicating information that cannot be achieved by other methods. These were compared to their counterparts- $\mathrm{a}$ brochure and written narrative. We find that the video was most effective at increasing financial literacy (by increasing the proportion of correct responses to financial literacy questions and decreasing “don't know" responses) and improving confidence. The video almost always outperformed the written narrative, while there were generally no significant differences between the visual tool and the brochure. All of the programs, including the written narrative, were effective at improving self-efficacy. The increased confidence as a result of most programs is particularly strong and robust for the visual tool and video treatments, in support of Bandura's (1989) social cognitive theory. 
Our results suggest that educational programs that engage the user emotionally or physically, involving vicarious experience and mastery experience (such as watching a video or using a visual tool), rather than text-based or passive educational programs (such as reading a narrative), are key for making gains in both financial literacy and confidence in financial knowledge. Static visual representations, such as those found in the brochure, do not seem to fit with the Bandura social cognitive theory methods for increasing selfefficacy. Yet we find that visual representations may help individuals to grasp complex concepts such as risk and return.

More research is needed to develop interactive visual tools that are easy to access. On the other hand, with increasing technological innovation, there will be a greater range of interactive visual tools that can be designed to help educate people on important life skills.

We would like to note that our methods are effective even though they are of short duration and are delivered via the Internet. Thus, these programs can easily be scalable to reach a large number of users. Since take-up is a major problem with existing educational programs, future work should also investigate whether the same selection bias is present in the take-up of online programs. In addition, future work should consider further exploring the link between knowledge, confidence, self-efficacy, and actionable behavior in practice. 


\section{References}

American Life Panel brochure. Santa Monica, CA: RAND Corporation, 2010. http://www.rand.org/pubs/corporate_pubs/CP508-2010-11.

Angrist, Joshua D., and Jörn-Steffen Pischke. Mostly harmless econometrics: An empiricist's companion. Princeton University Press, 2008: 161-166.

Atkinson, Adele. "Evidence of impact: an overview of financial education evaluations." Consumer Research 68 (2008).

Bandura, Albert. "Human agency in social cognitive theory." American psychologist 44, no. 9 (1989): 1175.

Bernheim, B. Douglas, Daniel M. Garrett, and Dean M. Maki. "Education and saving:: The long-term effects of high school financial curriculum mandates." Journal of Public Economics 80, no. 3 (2001): 435-465.

Bernheim, B. Douglas, and Daniel M. Garrett. "The effects of financial education in the workplace: evidence from a survey of households." Journal of Public Economics 87, no. 7 (2003): 1487-1519.

Bucher-Koenen, Tabea, Annamaria Lusardi, Rob Alessie, and Martin van Rooij. How Financially Literate are Women? Some New Perspectives on the Gender Gap. No. w31. Network for Studies on Pensions, Aging and Retirement, 2012.

Bruner, Jerome. "Life as narrative.” Social research 54, no. 1 (1987): 11-32.

Corby, Nancy H., Susan M. Enguídanos, and Linda S. Kay. "Development and use of role model stories in a community level HIV risk reduction intervention." Public Health Reports 111, no. Suppl 1 (1996): 54-58.

Davidhizar, Ruth, and Giny Lonser. "Storytelling as a teaching technique." Nurse Educator 28, no. 5 (2003): 217-221. 
Gist, Marilyn E. "The influence of training method on self- efficacy and idea generation among managers.” Personnel psychology 42, no. 4 (1989): 787-805.

Gutter, Michael, Zeynep Copur, and Selena Garrison. "Which Students are More Likely to Experience Financial Socialization Opportunities? Exploring the Relationship Between Financial Behaviors and Financial Well-Being of College Students.” Networks Financial Institute Working Paper 2009-WP (2009): 07.

Heinberg, Aileen, Angela Hung, Arie Kapteyn, Annamaria Lusardi, Anya Samek and Joanne Yoong. Five Steps to Planning Success: Experimental Evidence from US Households. Working Paper, Global Financial Literacy Excellence Center, 2014.

Hung, Angela A., Erik Meijer, Kata Mihaly and Joanne K. Yoong. Building Up, Spending Down: Financial Literacy, Retirement Savings Management, and Decumulation. RAND Working Paper No. WR-712, 2009

Holden, Gary. "The relationship of self-efficacy appraisals to subsequent health related outcomes: A meta-analysis.” Social work in health care 16, no. 1 (1991): 53-93.

Kaufmann, Christine, Martin Weber, and Emily Haisley. "The role of experience sampling and graphical displays on one's investment risk appetite."Management Science 59.2 (2013): 323-340.

Keim, D., Andrienko, G., Fekete, J.D., Görg, C., Kohlhammer, J., \& Melançon G. "Visual analytics: Definition, process, and challenges. " Information Visualization, 2008: 154-175.

Kroll, Yoram, Haim Levy, and Amnon Rapoport. "Experimental tests of the separation theorem and the capital asset pricing model." The American Economic Review (1988): 500-519. 
Lurie, Nicholas H., and Charlotte H. Mason. "Visual representation: Implications for decision making." Journal of Marketing (2007): 160-177.

Lusardi, Annamaria. "Financial Literacy and Financial Decision-Making." Numeracy 5, no. 1 (2012).

Lusardi, Annamaria, and Carlo de Bassa Scheresberg. Financial Literacy and High-Cost Borrowing in the United States. No. w18969. National Bureau of Economic Research, 2013.

Lusardi, Annamaria, Punam Keller, and Adam Keller. New Ways to Make People Save: A Social Marketing Approach, In Overcoming the Saving Slump: How to Increase the Effectiveness of Financial Education and Saving Programs. (2008) Ed. A. Lusardi. Chicago: University of Chicago Press: 209-236.

Lusardi, Annamaria, and Olivia S. Mitchell. "Baby boomer retirement security: The roles of planning, financial literacy, and housing wealth." Journal of monetary Economics 54, no. 1 (2007a): 205-224.

Lusardi, Annamaria, and Olivia Mitchell. "Financial literacy and retirement preparedness: Evidence and implications for financial education." Business Economics 42, no. 1 (2007b): 35-44.

Lusardi, Annamaria, and Olivia S. Mitchell. "Planning and Financial Literacy: How Do Women Fare? “ American Economic Review 98 (2008): 413-417.

Lusardi, Annamaria, and Olivia S. Mitchell. How ordinary consumers make complex economic decisions: Financial literacy and retirement readiness. No. w15350. National Bureau of Economic Research, 2009.

Lusardi, Annamaria, and Olivia S. Mitchell. "Financial Literacy and Planning: Implications for Retirement Wellbeing." In Financial Literacy: Implications for 
Retirement Security and the Financial Marketplace. O. S. Mitchell and A. Lusardi, eds. Oxford University Press, 2011a: 17-39.

Lusardi, Annamaria and Olivia S. Mitchell. "Financial Literacy around the World: An Overview." Journal of Pension Economics and Finance 10, no. 4 (2011b): $497-$ 508.

Lusardi, Annamaria and Olivia S. Mitchell. "Financial Literacy and Retirement Planning in the United States." Journal of Pension Economics and Finance 10, no. 4 (2011c): 509-525.

Lusardi, Annamaria and Olivia S. Mitchell. "The Economic Importance of Financial Literacy: Theory and Evidence. “ Journal of Economic Literature, March 2014, 52(1) $1-40$.

Lusardi, Annamaria, Olivia S. Mitchell, and Vilsa Curto. "Financial literacy among the young." Journal of Consumer Affairs 44, no. 2 (2010): 358-380.

Lusardi, Annamaria, Olivia S. Mitchell, and Vilsa Curto. Financial sophistication in the older population. No. w17863. National Bureau of Economic Research, 2012.

Mairal, Gaspar. "Narratives of risk.” Journal of Risk Research 11, no. 1-2 (2008): 41-54.

Meier, Stephan, and Charles Sprenger. Discounting financial literacy: Time preferences and participation in financial education programs, Journal of Economic Behavior and Organization 95 (2013): 159-174

Michielutte, Robert, Judy Bahnson, Mark B. Dignan, and Elissa M. Schroeder. "The use of illustrations and narrative text style to improve readability of a health education brochure.” Journal of Cancer Education 7, no. 3 (1992): 251-260. 
Norris, Stephen P., Sandra M. Guilbert, Martha L. Smith, Shahram Hakimelahi, and Linda M. Phillips. "A theoretical framework for narrative explanation in science.” Science Education 89, no. 4 (2005): 535-563.

Petraglia, Joseph. "Narrative intervention in behavior and public health." Journal of health communication 12, no. 5 (2007): 493-505.

Rudolph, Stephen, Anya Savikhin, and David S. Ebert. "FinVis: Applied visual analytics for personal financial planning." In Visual Analytics Science and Technology, 2009. VAST 2009. IEEE Symposium on, pp. 195-202. IEEE, 2009.

Savikhin, Anya, “The Application of Visual Analytics to Financial Decision-Making and Risk Management: Notes from Behavioral Economics," in Lemieux, Victoria (Ed) Financial Analysis and Risk Management: Data Governance, Analytics and Life Cycle Management, Springer, Heidelberg, 2012.

Savikhin, Anya, Hon Cheong Lam, Brian Fisher, and David S. Ebert. “An experimental study of financial portfolio selection with visual analytics for decision support." In System Sciences (HICSS), 2011 44th Hawaii International Conference on, pp. 1-10. IEEE, 2011.

Shockey, Susan S., and Sharon B. Seiling. "Moving into action: Application of the transtheoretical model of behavior change to financial education." Financial Counseling and Planning 15, no. 1 (2004): 41-52.

Thomas, James J., and Kristin A. Cook, eds. Illuminating the path: The research and development agenda for visual analytics. IEEE Computer Society Press, 2005.

Van Rooij, Maarten, Annamaria Lusardi, and Rob Alessie. 2011. Financial Literacy and Stock Market Participation. Journal of Financial Economics 101(2): 449-472. 
Van Rooij, Maarten, Annamaria Lusardi, and Rob Alessie. 2012. Financial Literacy, Retirement Planning, and Households Wealth. Economic Journal 122: 449-478

Van Wijk, Jarke J. “The value of visualization.” In Visualization, 2005. VIS 05. IEEE, pp. 79-86. IEEE, 2005.

Yoong, Joanne. 2011. Financial Illiteracy and Stock Market Participation: Evidence from the RAND American Life Panel. In Financial Literacy: Implications for Retirement Security and the Financial Marketplace. Eds O. S. Mitchell and A. Lusardi. Oxford: Oxford University Press: 76-97. 


\section{TABLES}

Table 1: Treatment Summary

\begin{tabular}{|l|l|l|l|l|l|}
\hline \multirow{2}{*}{$\begin{array}{l}\text { (1) Total } \\
\text { Number of Participants }\end{array}$} & $\begin{array}{l}\text { (A) } \\
\text { Control }\end{array}$ & $\begin{array}{l}\text { Stories } \\
\text { Video }\end{array}$ & $\begin{array}{l}\text { (C) } \\
\text { Narrative }\end{array}$ & $\begin{array}{l}\text { Visuals } \\
\text { Brochure }\end{array}$ & $\begin{array}{l}\text { (E) } \\
\text { Visual Tool }\end{array}$ \\
\cline { 2 - 6 } & 388 & 115 & 133 & 127 & 129 \\
\hline $\begin{array}{l}\text { (2) Number of Participants asked } \\
\text { whether they could view the video, } \\
\text { brochure or visual tool } *\end{array}$ & $\begin{array}{l}264 \\
(68 \% \text { of } \\
\text { total)** }\end{array}$ & $\begin{array}{l}111 \\
(97 \% \text { of } \\
\text { total) }\end{array}$ & $\begin{array}{l}93 \\
(70 \% \text { of } \\
\text { total)** }\end{array}$ & $\begin{array}{l}63 \\
(50 \% \text { of } \\
\text { total) }\end{array}$ & $\begin{array}{l}82 \\
(64 \% \text { of } \\
\text { total) }\end{array}$ \\
\hline $\begin{array}{l}\text { (3) Number responding positively } \\
\text { to whether they could view the } \\
\text { video, brochure or visual tool }\end{array}$ & $\begin{array}{l}264 \\
\text { (assumed) }\end{array}$ & $\begin{array}{l}84 \\
(76 \% \text { of } \\
\text { asked) }\end{array}$ & $\begin{array}{l}93 \\
\text { (assumed) }\end{array}$ & $\begin{array}{l}51 \\
(81 \% \text { of } \\
\text { asked) }\end{array}$ & $\begin{array}{l}53 \\
(65 \% \text { of } \\
\text { asked) }\end{array}$ \\
\hline
\end{tabular}

*The ability to view question was asked several weeks after the study opened, so ability to view is not available for all participants.

**Respondents assigned to control group and narrative treatment were not asked, but we only include those participants who took the assessment after question was asked for other treatments.

Table 2: Demographic Background of Participants

\begin{tabular}{|c|c|c|c|c|c|c|}
\hline & Overall & Control & Video & Narrative & Brochure & Tool \\
\hline Age at Assessment & 49.50 & 50.22 & 47.95 & 48.90 & 49.89 & 48.94 \\
\hline Proportion Female & $60.99 \%$ & $56.96 \%$ & $66.96 \%$ & $62.41 \%$ & $64.57 \%$ & $62.79 \%$ \\
\hline \multicolumn{7}{|l|}{ Race \& Ethnicity } \\
\hline Proportion Caucasian & $79.82 \%$ & $80.15 \%$ & $78.26 \%$ & $72.93 \%$ & $84.25 \%$ & $82.95 \backslash \%$ \\
\hline $\begin{array}{l}\text { Proportion African } \\
\text { American }\end{array}$ & $10.99 \%$ & $11.60 \%$ & $11.30 \%$ & $14.29 \%$ & $7.87 \%$ & $8.53 \%$ \\
\hline $\begin{array}{l}\text { Proportion "Other } \\
\text { Race" }\end{array}$ & $9.19 \%$ & $8.25 \%$ & $10.43 \%$ & $12.78 \%$ & $7.87 \%$ & $8.53 \%$ \\
\hline Proportion Hispanic $^{1}$ & $14.80 \%$ & $13.66 \%$ & $13.91 \%$ & $18.80 \%$ & $19.69 \%$ & $10.08 \%$ \\
\hline \multicolumn{7}{|l|}{ Education/Employment } \\
\hline Proportion Working & $57.96 \%$ & $59.54 \%$ & $65.22 \%$ & $52.63 \%$ & $55.12 \%$ & $55.04 \%$ \\
\hline $\begin{array}{l}\text { Median of Highest } \\
\text { Education Attained }\end{array}$ & $\begin{array}{l}\text { Some } \\
\text { college, } \\
\text { no } \\
\text { degree }\end{array}$ & $\begin{array}{l}\text { Associate } \\
\text { degree } \\
\text { (Occupational } \\
\text { School) }\end{array}$ & $\begin{array}{l}\text { Some } \\
\text { college, } \\
\text { no } \\
\text { degree }\end{array}$ & $\begin{array}{l}\text { Associate } \\
\text { degree } \\
\text { (Occupational } \\
\text { School) }\end{array}$ & $\begin{array}{l}\text { Some } \\
\text { college, } \\
\text { no degree }\end{array}$ & $\begin{array}{l}\text { Some } \\
\text { college, } \\
\text { no } \\
\text { degree }\end{array}$ \\
\hline $\begin{array}{l}\text { Median Total Annual } \\
\text { Family Income } \\
\text { (bracketed) }\end{array}$ & $\begin{array}{l}\$ 40,000- \\
\$ 49,999\end{array}$ & $\begin{array}{l}\$ 40,000- \\
\$ 49,999\end{array}$ & $\begin{array}{l}\$ 40,000- \\
\$ 49,999\end{array}$ & $\begin{array}{l}\$ 40,000- \\
\$ 49,999\end{array}$ & $\begin{array}{l}\$ 35,000- \\
\$ 39,999\end{array}$ & $\begin{array}{l}\$ 50,000- \\
\$ 59,999\end{array}$ \\
\hline \multicolumn{7}{|l|}{$\begin{array}{l}\text { Household } \\
\text { Composition }\end{array}$} \\
\hline $\begin{array}{l}\text { Number of People in } \\
\text { Household }\end{array}$ & 2.16 & 2.14 & 2.24 & 2.28 & 2.17 & 1.99 \\
\hline $\begin{array}{l}\% \text { Married or living } \\
\text { with partner }\end{array}$ & $61.32 \%$ & $62.11 \%$ & $66.96 \%$ & $63.91 \%$ & $54.33 \%$ & $58.14 \%$ \\
\hline $\begin{array}{l}\text { \% Divorced, } \\
\text { separated, widowed }\end{array}$ & $19.96 \%$ & $18.56 \%$ & $16.52 \%$ & $18.05 \%$ & $28.35 \%$ & $20.93 \%$ \\
\hline $\begin{array}{l}\text { \% Single/never } \\
\text { Married }\end{array}$ & $18.72 \%$ & $19.33 \%$ & $16.52 \%$ & $18.05 \%$ & $17.32 \%$ & $20.93 \%$ \\
\hline$N$ & 892 & 388 & 115 & 133 & 127 & 129 \\
\hline
\end{tabular}

*Standard errors in parentheses

${ }^{1}$ Race does not add to $100 \%$ since Ethnicity - Hispanic or not, is a separate question from Race 
Table 3: Proportion Correct/Don't Know by Treatment (Q2, Q3, and Q4)

\begin{tabular}{|c|c|c|c|c|c|}
\hline & \multirow[b]{2}{*}{$\begin{array}{l}\text { (A) } \\
\text { Control }\end{array}$} & \multicolumn{2}{|l|}{ Stories } & \multicolumn{2}{|l|}{ Visuals } \\
\hline & & $\begin{array}{l}\text { (B) } \\
\text { Video }\end{array}$ & $\begin{array}{l}\text { (C) } \\
\text { Narrative }\end{array}$ & $\begin{array}{l}\text { (D) } \\
\text { Brochure }\end{array}$ & $\begin{array}{l}\text { (E) } \\
\text { Visual Tool }\end{array}$ \\
\hline $\begin{array}{r}\text { Proportion Correct - } \\
\text { All Participants }\end{array}$ & $0.71(0.02)$ & $0.80(0.03)$ & $0.74(0.03)$ & $0.77(0.03)$ & $0.73(0.03)$ \\
\hline $\begin{array}{l}\text { Proportion responding } \\
\text { 'Don't Know' }\end{array}$ & $0.17(0.02)$ & $0.08(0.02)$ & $0.13(0.03)$ & $0.09(0.02)$ & $0.13(0.02)$ \\
\hline $\begin{array}{l}\text { Proportion Correct - } \\
\text { Treated Participants }\end{array}$ & $0.69(0.02)$ & $0.86(0.03)$ & $0.73(0.03)$ & $0.78(0.04)$ & $0.83(0.04)$ \\
\hline $\begin{array}{l}\text { Proportion responding } \\
\text { 'Don't Know' }\end{array}$ & $0.18(0.02)$ & $0.04(0.01)$ & $0.12(0.03)$ & $0.08(0.03)$ & $0.07(0.03)$ \\
\hline Number of subjects & $\begin{array}{l}386 \\
262 \text { Treated }\end{array}$ & $\begin{array}{l}111 \\
84 \text { Treated }\end{array}$ & $\begin{array}{l}130 \\
93 \text { Treated }\end{array}$ & $\begin{array}{l}124 \\
51 \text { Treated }\end{array}$ & $\begin{array}{l}125 \\
53 \text { Treated }\end{array}$ \\
\hline
\end{tabular}

*Standard errors in parentheses

Table 4: Confidence and Self-Efficacy by Treatment (Q1 and Q5)

\begin{tabular}{|l|l|l|l|l|l|}
\hline & \multicolumn{3}{|l|}{ Stories } & \multicolumn{2}{l|}{ Visuals } \\
\cline { 2 - 6 } & $\begin{array}{l}\mathbf{( A )} \\
\text { Control }\end{array}$ & $\begin{array}{l}\mathbf{( B )} \\
\text { Video }\end{array}$ & $\begin{array}{l}\mathbf{( C )} \\
\text { Narrative }\end{array}$ & $\begin{array}{l}\text { (D) } \\
\text { Brochure }\end{array}$ & $\begin{array}{l}\text { (E) } \\
\text { Visual Tool }\end{array}$ \\
\hline $\begin{array}{l}\text { Q5 - Confidence in Knowledge } \\
\text { All Participants }\end{array}$ & $2.84(0.05)$ & $3.08(0.10)$ & $2.98(0.08)$ & $2.98(0.08)$ & $3.16(0.09)$ \\
\hline $\begin{array}{l}\text { Q1 - Self Efficacy } \\
\text { All Participants }\end{array}$ & $2.98(0.04)$ & $3.41(0.07)$ & $3.33(0.07)$ & $3.34(0.07)$ & $3.38(0.07)$ \\
\hline$N$ & 387 & 111 & 130 & 125 & 125 \\
\hline $\begin{array}{l}\text { Q5 - Confidence in Knowledge } \\
\text { Treated Participants }\end{array}$ & $2.77(0.06)$ & $3.18(0.11)$ & $2.96(0.10)$ & $3.12(0.13)$ & $3.42(0.12)$ \\
\hline $\begin{array}{l}\text { Q1 - Self Efficacy } \\
\text { Treated Participants }\end{array}$ & $2.97(0.05)$ & $3.60(0.06)$ & $3.37(0.08)$ & $3.35(0.08)$ & $3.51(0.10)$ \\
\hline$N$ & 263 & 84 & 90 & 51 & 53 \\
\hline
\end{tabular}

*Standard errors in parentheses 
Table 5: OLS Regressions for Intent to Treat

\begin{tabular}{|c|c|c|c|c|c|c|c|c|}
\hline VARIABLES & $\begin{array}{c}(1) \\
\text { Proportion } \\
\text { Correct }\end{array}$ & $\begin{array}{c}(2) \\
\text { Proportion } \\
\text { Correct } \\
\end{array}$ & $\begin{array}{l}\text { (3) } \\
\text { Proportion don’t } \\
\text { know (DK) }\end{array}$ & $\begin{array}{l}\quad(4) \\
\text { Proportion don't } \\
\text { know (DK) }\end{array}$ & $\begin{array}{c}\text { (5) } \\
\text { Confidence }\end{array}$ & $\begin{array}{c}\text { (6) } \\
\text { Confidence } \\
\end{array}$ & $\begin{array}{c}(7) \\
\text { Self- } \\
\text { Efficacy } \\
\end{array}$ & $\begin{array}{c}(8) \\
\text { Self- } \\
\text { Efficacy } \\
\end{array}$ \\
\hline Video & $\begin{array}{c}0.0876 * * \\
(0.0354)\end{array}$ & $\begin{array}{l}0.101 * * * \\
(0.0305)\end{array}$ & $\begin{array}{c}-0.0922 * * * \\
(0.0283)\end{array}$ & $\begin{array}{c}-0.0968 * * * \\
(0.0264)\end{array}$ & $\begin{array}{c}0.237 * * \\
(0.107)\end{array}$ & $\begin{array}{c}0.271^{* * * *} \\
(0.100)\end{array}$ & $\begin{array}{c}0.435^{* * * *} \\
(0.0849)\end{array}$ & $\begin{array}{c}0.457 * * * \\
(0.0818)\end{array}$ \\
\hline Narrative & $\begin{array}{c}0.0217 \\
(0.0334)\end{array}$ & $\begin{array}{l}0.0482 * \\
(0.0288)\end{array}$ & $\begin{array}{l}-0.0347 \\
(0.0268)\end{array}$ & $\begin{array}{c}-0.0452 * \\
(0.0250)\end{array}$ & $\begin{array}{c}0.140 \\
(0.100)\end{array}$ & $\begin{array}{c}0.180 * \\
(0.0947)\end{array}$ & $\begin{array}{c}0.351 * * * \\
(0.0799)\end{array}$ & $\begin{array}{c}0.369 * * * \\
(0.0771)\end{array}$ \\
\hline Brochure & $\begin{array}{c}0.0520 \\
(0.0340)\end{array}$ & $\begin{array}{c}0.0796 * * * \\
(0.0292)\end{array}$ & $\begin{array}{c}-0.0783 * * * \\
(0.0272)\end{array}$ & $\begin{array}{c}-0.0977 * * * \\
(0.0254)\end{array}$ & $\begin{array}{c}0.140 \\
(0.102)\end{array}$ & $\begin{array}{l}0.205 * * \\
(0.0958)\end{array}$ & $\begin{array}{l}0.357 * * * \\
(0.0811)\end{array}$ & $\begin{array}{l}0.386 * * * \\
(0.0780)\end{array}$ \\
\hline Tool & $\begin{array}{c}0.0192 \\
(0.0339)\end{array}$ & $\begin{array}{c}0.0355 \\
(0.0291)\end{array}$ & $\begin{array}{l}-0.0409 \\
(0.0271)\end{array}$ & $\begin{array}{l}-0.0495^{*} \\
(0.0252)\end{array}$ & $\begin{array}{c}0.316^{* * *} \\
(0.102)\end{array}$ & $\begin{array}{c}0.371 * * * \\
(0.0958)\end{array}$ & $\begin{array}{c}0.405 * * * \\
(0.0811)\end{array}$ & $\begin{array}{c}0.415 * * * \\
(0.0780)\end{array}$ \\
\hline Female & & $\begin{array}{c}-0.0607 * * * \\
(0.0198)\end{array}$ & & $\begin{array}{c}0.0359 * * \\
(0.0173)\end{array}$ & & $\begin{array}{c}-0.448^{* * *} \\
(0.0652)\end{array}$ & & $\begin{array}{l}-0.0252 \\
(0.0531)\end{array}$ \\
\hline Age at Assessment & & $\begin{array}{c}0.00326 * * * \\
(0.000680)\end{array}$ & & $\begin{array}{c}-0.00166 * * * \\
(0.000590)\end{array}$ & & $\begin{array}{c}0.00293 \\
(0.00224)\end{array}$ & & $\begin{array}{c}0.00409 * * \\
(0.00182)\end{array}$ \\
\hline Family Income & & $\begin{array}{c}0.0151 * * * \\
(0.00285)\end{array}$ & & $\begin{array}{c}-0.0108 * * * \\
(0.00249)\end{array}$ & & $\begin{array}{c}0.0243 * * * \\
(0.00937)\end{array}$ & & $\begin{array}{c}0.0256 * * * \\
(0.00762)\end{array}$ \\
\hline Work Status & & $\begin{array}{l}0.0440 * * \\
(0.0214)\end{array}$ & & $\begin{array}{l}-0.0332 * \\
(0.0186)\end{array}$ & & $\begin{array}{c}0.0328 \\
(0.0705)\end{array}$ & & $\begin{array}{l}-0.0529 \\
(0.0574)\end{array}$ \\
\hline Education & & $\begin{array}{c}0.0316 * * * \\
(0.00480)\end{array}$ & & $\begin{array}{c}-0.0188 * * * \\
(0.00419)\end{array}$ & & $\begin{array}{c}0.0774 * * * \\
(0.0158)\end{array}$ & & $\begin{array}{c}0.0423 * * * \\
(0.0129)\end{array}$ \\
\hline Black & & $\begin{array}{c}-0.131 * * * \\
(0.0318)\end{array}$ & & $\begin{array}{c}0.0833 * * * \\
(0.0277)\end{array}$ & & $\begin{array}{l}-0.108 \\
(0.105)\end{array}$ & & $\begin{array}{l}-0.216 * * \\
(0.0853)\end{array}$ \\
\hline Hispanic & & $\begin{array}{c}-0.167 * * * \\
(0.0305)\end{array}$ & & $\begin{array}{c}0.0611 * * \\
(0.0265)\end{array}$ & & $\begin{array}{l}-0.0537 \\
(0.100)\end{array}$ & & $\begin{array}{c}-0.225 * * * \\
(0.0814)\end{array}$ \\
\hline Other race & & $\begin{array}{l}-0.0448 \\
(0.0372)\end{array}$ & & $\begin{array}{c}0.0345 \\
(0.0322)\end{array}$ & & $\begin{array}{l}-0.115 \\
(0.123)\end{array}$ & & $\begin{array}{c}-0.124 \\
(0.0997)\end{array}$ \\
\hline Constant & $\begin{array}{c}0.714 * * * \\
(0.0168)\end{array}$ & $\begin{array}{c}0.0865 \\
(0.0668)\end{array}$ & $\begin{array}{c}0.168 * * * \\
(0.0135)\end{array}$ & $\begin{array}{c}0.554 * * * \\
(0.0581)\end{array}$ & $\begin{array}{c}2.844 * * * \\
(0.0504)\end{array}$ & $\begin{array}{c}1.840 * * * \\
(0.220)\end{array}$ & $\begin{array}{c}2.979 * * * \\
(0.0401)\end{array}$ & $\begin{array}{c}2.143 * * * \\
(0.179)\end{array}$ \\
\hline Observations & 876 & 873 & 892 & 889 & 876 & 873 & 878 & 875 \\
\hline R-squared & 0.008 & 0.286 & 0.017 & 0.166 & 0.014 & 0.145 & 0.057 & 0.148 \\
\hline
\end{tabular}

Standard errors in parentheses, ${ }^{* * *} \mathrm{p}<0.01,{ }^{* *} \mathrm{p}<0.05,{ }^{*} \mathrm{p}<0.1$; Dependent variables in columns 1-4 are proportions correct (1-2) or “don't know" (3-4) to Q2-Q4;

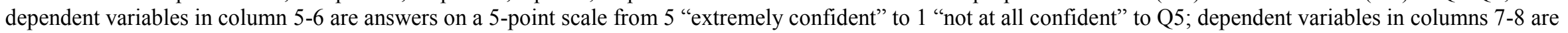
answers on a 4-point scale from 4 "exactly true" to 1 "not at all true" to Q1; see Appendix D for the exact wording of the questions. 
Table 6: IV Estimates for Treatment on Treated

\begin{tabular}{|c|c|c|c|c|c|c|c|c|}
\hline VARIABLES & $\begin{array}{c}(1) \\
\text { Proportion } \\
\text { Correct }\end{array}$ & $\begin{array}{c}(2) \\
\text { Proportion } \\
\text { Correct }\end{array}$ & $\begin{array}{c}(3) \\
\text { Proportion don't } \\
\text { know }\end{array}$ & $\begin{array}{c}(4) \\
\text { Proportion don't } \\
\text { know }\end{array}$ & $\begin{array}{c}\text { (5) } \\
\text { Confidence }\end{array}$ & $\begin{array}{c}\text { (6) } \\
\text { Confidence }\end{array}$ & $\begin{array}{c}(7) \\
\text { Self- } \\
\text { Efficacy } \\
\end{array}$ & $\begin{array}{c}(8) \\
\text { Self- } \\
\text { Efficacy }\end{array}$ \\
\hline Video, predicted & $\begin{array}{l}0.116 * * \\
(0.0468)\end{array}$ & $\begin{array}{c}0.134 * * * \\
(0.0403)\end{array}$ & $\begin{array}{c}-0.122 * * * \\
(0.0374)\end{array}$ & $\begin{array}{c}-0.128 * * * \\
(0.0349)\end{array}$ & $\begin{array}{c}0.313 * * \\
(0.141)\end{array}$ & $\begin{array}{c}0.358 * * * \\
(0.133)\end{array}$ & $\begin{array}{c}0.575 * * * \\
(0.112)\end{array}$ & $\begin{array}{c}0.604 * * * \\
(0.108)\end{array}$ \\
\hline Narrative, predicted & $\begin{array}{c}0.0217 \\
(0.0334)\end{array}$ & $\begin{array}{l}0.0482 * \\
(0.0288)\end{array}$ & $\begin{array}{l}-0.0347 \\
(0.0268)\end{array}$ & $\begin{array}{l}-0.0452 * \\
(0.0250)\end{array}$ & $\begin{array}{c}0.140 \\
(0.100)\end{array}$ & $\begin{array}{c}0.180 * \\
(0.0947)\end{array}$ & $\begin{array}{c}0.351 * * * \\
(0.0799)\end{array}$ & $\begin{array}{c}0.369 * * * \\
(0.0771)\end{array}$ \\
\hline Brochure, predicted & $\begin{array}{c}0.0642 \\
(0.0420)\end{array}$ & $\begin{array}{c}0.0983 * * * \\
(0.0360)\end{array}$ & $\begin{array}{c}-0.0967 * * * \\
(0.0336)\end{array}$ & $\begin{array}{c}-0.121 * * * \\
(0.0314)\end{array}$ & $\begin{array}{c}0.173 \\
(0.126)\end{array}$ & $\begin{array}{c}0.253 * * \\
(0.118)\end{array}$ & $\begin{array}{c}0.441 * * * \\
(0.100)\end{array}$ & $\begin{array}{c}0.477 * * * \\
(0.0963)\end{array}$ \\
\hline Tool, predicted & $\begin{array}{c}0.0297 \\
(0.0524)\end{array}$ & $\begin{array}{c}0.0550 \\
(0.0450)\end{array}$ & $\begin{array}{l}-0.0633 \\
(0.0419)\end{array}$ & $\begin{array}{c}-0.0766^{*} \\
(0.0390)\end{array}$ & $\begin{array}{c}0.489 * * * \\
(0.157)\end{array}$ & $\begin{array}{c}0.573 * * * \\
(0.148)\end{array}$ & $\begin{array}{c}0.626 * * * \\
(0.126)\end{array}$ & $\begin{array}{c}0.643 * * * \\
(0.121)\end{array}$ \\
\hline Female & & $\begin{array}{c}-0.0607 * * * \\
(0.0198)\end{array}$ & & $\begin{array}{c}0.0359 * * \\
(0.0173)\end{array}$ & & $\begin{array}{c}-0.448 * * * \\
(0.0652)\end{array}$ & & $\begin{array}{l}-0.0252 \\
(0.0531)\end{array}$ \\
\hline Age at Assessment & & $\begin{array}{c}0.00326 * * * \\
(0.000680)\end{array}$ & & $\begin{array}{c}-0.00166^{* * *} \\
(0.000590)\end{array}$ & & $\begin{array}{c}0.00293 \\
(0.00224)\end{array}$ & & $\begin{array}{c}0.00409 * * \\
(0.00182)\end{array}$ \\
\hline Family Income & & $\begin{array}{c}0.0151 * * * \\
(0.00285)\end{array}$ & & $\begin{array}{c}-0.0108 * * * \\
(0.00249)\end{array}$ & & $\begin{array}{c}0.0243 * * * \\
(0.00937)\end{array}$ & & $\begin{array}{c}0.0256 * * * \\
(0.00762)\end{array}$ \\
\hline Work status & & $\begin{array}{c}0.0440 * * \\
(0.0214)\end{array}$ & & $\begin{array}{c}-0.0332 * \\
(0.0186)\end{array}$ & & $\begin{array}{c}0.0328 \\
(0.0705)\end{array}$ & & $\begin{array}{l}-0.0529 \\
(0.0574)\end{array}$ \\
\hline Education & & $\begin{array}{c}0.0316^{* * *} \\
(0.00480)\end{array}$ & & $\begin{array}{c}-0.0188 * * * \\
(0.00419)\end{array}$ & & $\begin{array}{c}0.0774 * * * \\
(0.0158)\end{array}$ & & $\begin{array}{c}0.0423 * * * \\
(0.0129)\end{array}$ \\
\hline Black & & $\begin{array}{c}-0.131 * * * \\
(0.0318)\end{array}$ & & $\begin{array}{c}0.0833 * * * \\
(0.0277)\end{array}$ & & $\begin{array}{l}-0.108 \\
(0.105)\end{array}$ & & $\begin{array}{c}-0.216^{* *} \\
(0.0853)\end{array}$ \\
\hline Hispanic & & $\begin{array}{c}-0.167 * * * \\
(0.0305)\end{array}$ & & $\begin{array}{l}0.0611 * * \\
(0.0265)\end{array}$ & & $\begin{array}{l}-0.0537 \\
(0.100)\end{array}$ & & $\begin{array}{c}-0.225 * * * \\
(0.0814)\end{array}$ \\
\hline Other race & & $\begin{array}{l}-0.0448 \\
(0.0372)\end{array}$ & & $\begin{array}{c}0.0345 \\
(0.0322)\end{array}$ & & $\begin{array}{l}-0.115 \\
(0.123)\end{array}$ & & $\begin{array}{c}-0.124 \\
(0.0997)\end{array}$ \\
\hline Constant & $\begin{array}{c}0.714^{* * *} \\
(0.0168)\end{array}$ & $\begin{array}{c}0.0865 \\
(0.0668)\end{array}$ & $\begin{array}{c}0.168 * * * \\
(0.0135)\end{array}$ & $\begin{array}{c}0.554 * * * \\
(0.0581)\end{array}$ & $\begin{array}{c}2.844 * * * \\
(0.0504)\end{array}$ & $\begin{array}{c}1.840 * * * \\
(0.220)\end{array}$ & $\begin{array}{c}2.979 * * * \\
(0.0401)\end{array}$ & $\begin{array}{c}2.143 * * * \\
(0.179)\end{array}$ \\
\hline Observations & 876 & 873 & 892 & 889 & 876 & 873 & 878 & 875 \\
\hline R-squared & 0.008 & 0.286 & 0.017 & 0.166 & 0.014 & 0.145 & 0.057 & 0.148 \\
\hline
\end{tabular}




\section{FIGURES}

Figure 1: FinVis Tool

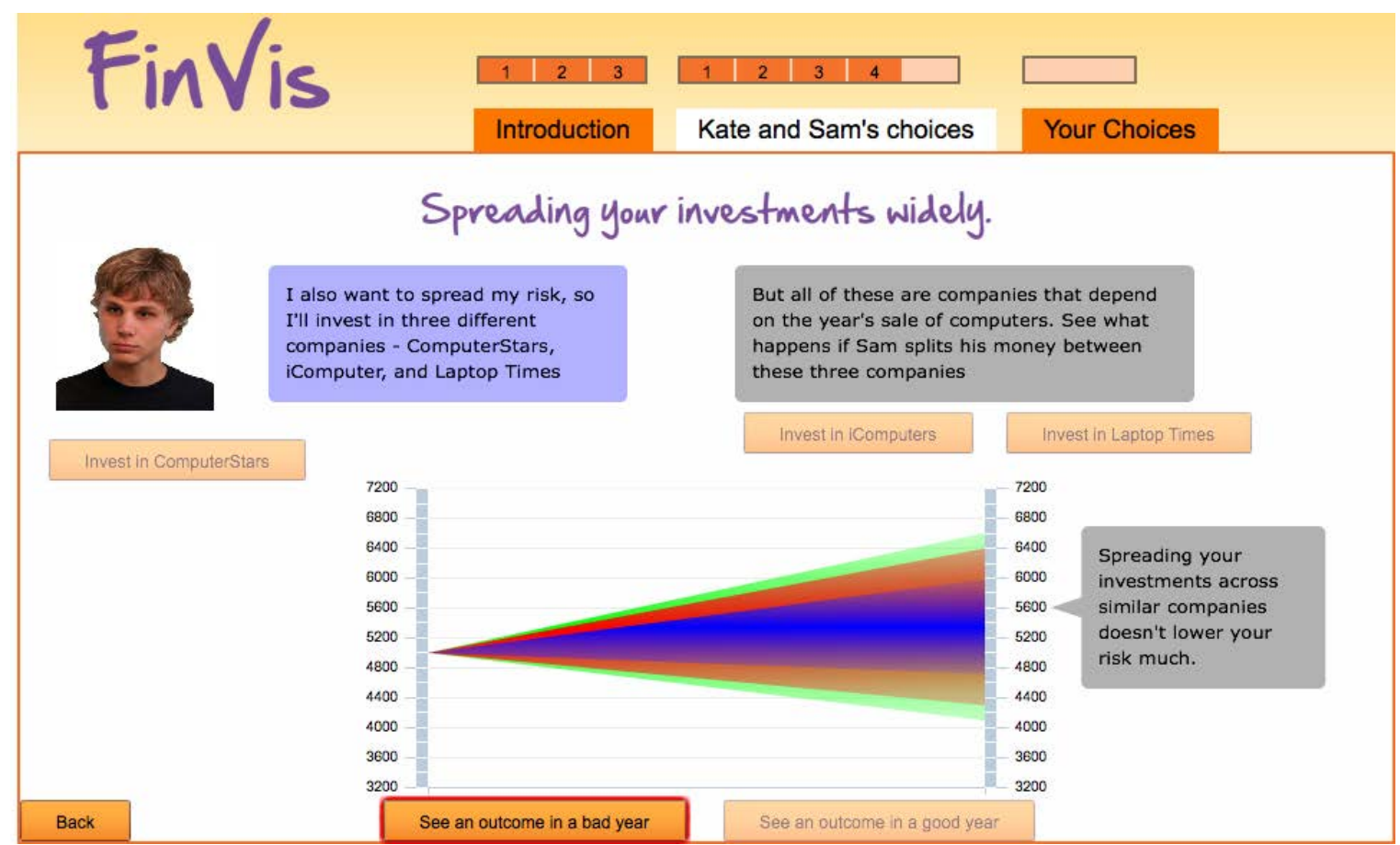

One screen from the "tutorial" component of FinVis

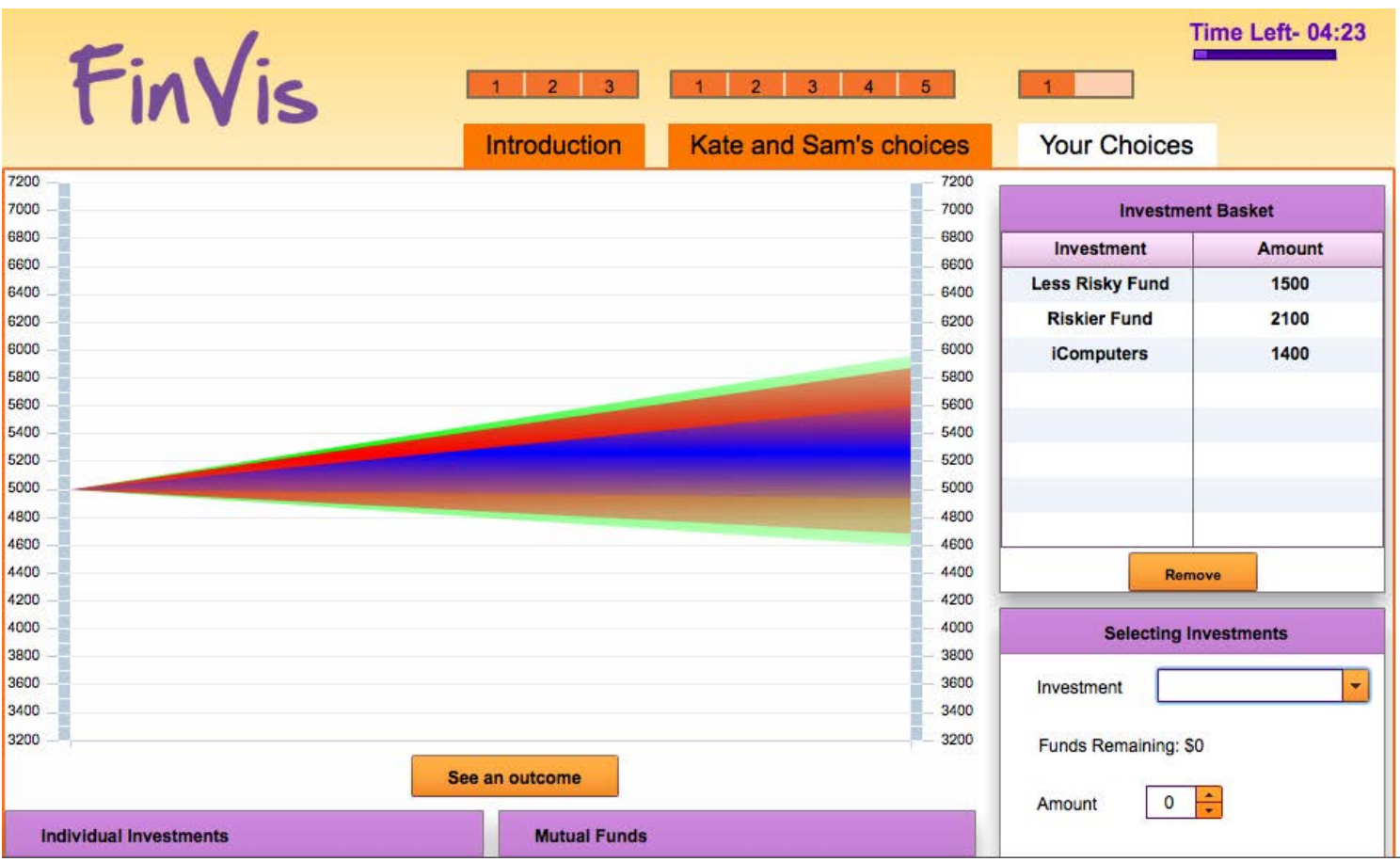




\section{Appendix A: Narratives}

Videos can be accessed here: http://www.youtube.com/watch?v=DO6FPJw E1Q

The narrative was designed to explain and encourage risk diversification. In the narrative, two siblings helping their grandparents move house debate how to invest the $\$ 12,000$ gift they have received. Older sister Kate advocates diversifying into different sectors and degrees of risk. She manages to convince younger brother Sam that it's unwise to put all his $\$ 12,000$ into the company he works for just because the company is doing well. Both Kate and Sam are young people at an early stage in their own earning and saving.

\section{Written story}

Sam reflected for a moment. "Kate, what are you planning to do with it all? $\$ 12,000$ each..."

"I'm going to invest mine," said Kate -- and she lowered her voice. "Grandma told me last night that she wants each of us to have a little "nest egg"."

Sam chuckled. "Eggs. That 's one of Grandma's favorite words." And he imitated his grandmother's voice: "Sam, you listen to your Grandparents and don't put all your eggs in one basket. We didn't and you and your parents have all been given a good start in life."

"You may laugh", Said Kate, “but we had a Planning for your Future seminar in my senior year, and they also told us about not putting all our eggs in one basket. I'm going to spread the money around."

They both began emptying the highest kitchen shelf. Their grandmother had so many plates. What could she possibly have wanted with them all?

"But Kate, "said Sam, "Why not just put it somewhere you know is safe? Some really really safe stock."

Kate shook her head: "Well, what is really really safe, Sam? Did you know that some really famous firms have ended up going bust? Anyway, if you want to make your money grow over time, they said that you have to take some risk."

"But what's one have to do with the other?" protested Sam.

\section{Video}

SAM

What are you planning to do with the $\$ 12,000$ they gave you?

KATE

I'm investing mine. Grandma told me last night that she wants each of us to have a little "nest egg".

SAM

Eggs. That's one of her favorite words. "Sam, you listen to your Grandparents and don't put all your eggs in one basket. We didn't and you and your parents have all been

given a good start in life." Kate smiles. 


\section{KATE}

Well, I had this Planning for your Future seminar my senior year, and they also told us about not putting all our eggs in one basket. I'm gonna spread the money around.

\section{SAM}

Why not just put it somewhere you know is safe? Some really, really safe stock.

\section{KATE}

Well, what is really, really safe?? Did you know that some really famous firms have ended up going bust? Anyway, if you want to make your money grow over time, they said that you have to take some risk.

\section{SAM}

What's one have to do with the other? 


\section{Appendix B: Visuals}

The interactive visual tool can be accessed at: http://anyasamek.com/finvis/

First, the visual tool explains risk and return (including the correlation between these two characteristics), and explains the difference between stocks and (stocks) funds. Second, the tool provides an interactive explanation of the benefits of diversification, both across stocks and funds. Third, the tool allows the user to choose a set of (hypothetical) stocks and funds that are in line with his/her risk preferences.

Figure 1 is a screenshot of the risk cone. The visual displayed represents the amount of money invested in hypothetical Year 1 (the left Y-axis) and the probable values that the portfolio may take on in hypothetical Year 2 (the right Y-axis). The risk cone uses a "risk gradient" that is darker for more likely outcomes and lighter for less likely outcomes. This screenshot features a portfolio with several different assets, and the amount of risk that each asset contributes is highlighted in a different color for each asset. Assets added at the beginning of the decision period appear in the middle of the cone, while assets added later appear on the outside of the cone. An important interactive characteristic of the risk cone is the ability of the user to "sample possible outcomes." When the user clicks this button, he/she is able to view a possible outcome drawn from the underlying distribution, which appears as a small arrow directly on the risk cone.

Figure B1: Visualized Risk and Return in FinVis 2.0

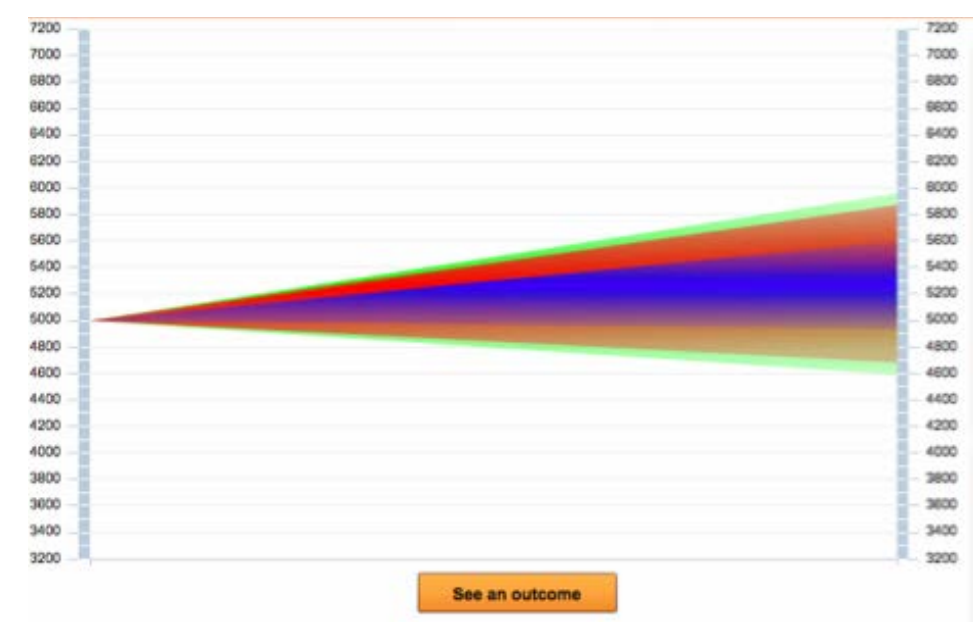

In the tutorial component of the tool, "Kate" and "Sam" ask questions about risk and return, which are answered when the user clicks on action buttons on the screen that adjust the visual and explain the key concepts. Figure B2 provides a screenshot of one of the tutorial screens. 5 screens are used to explain the key concepts, and the user can go back to screens to repeat explanations that were confusing. Each of the tutorial pages utilizes the core visual tool from Figure 1. In the first part of the tutorial, we introduce a more risky and a less risky fund. Kate invests in the more risky fund, while Sam invests in the less risky fund. Second, we introduce the idea that while year-to-year returns may be volatile, returns even out and come closer to the expected return over time. Third, we introduce risk diversification, whereby Kate invests in several different stocks to reduce her risk, while Sam invests in several stocks of the same type, which do not reduce his risk (they were generated with a correlation of 1.0). Finally, Kate and Sam discuss the difference between stocks and funds, and Kate points out the benefit of funds, which already contain many different stocks. 
Figure B2: Tutorial Component Screenshot

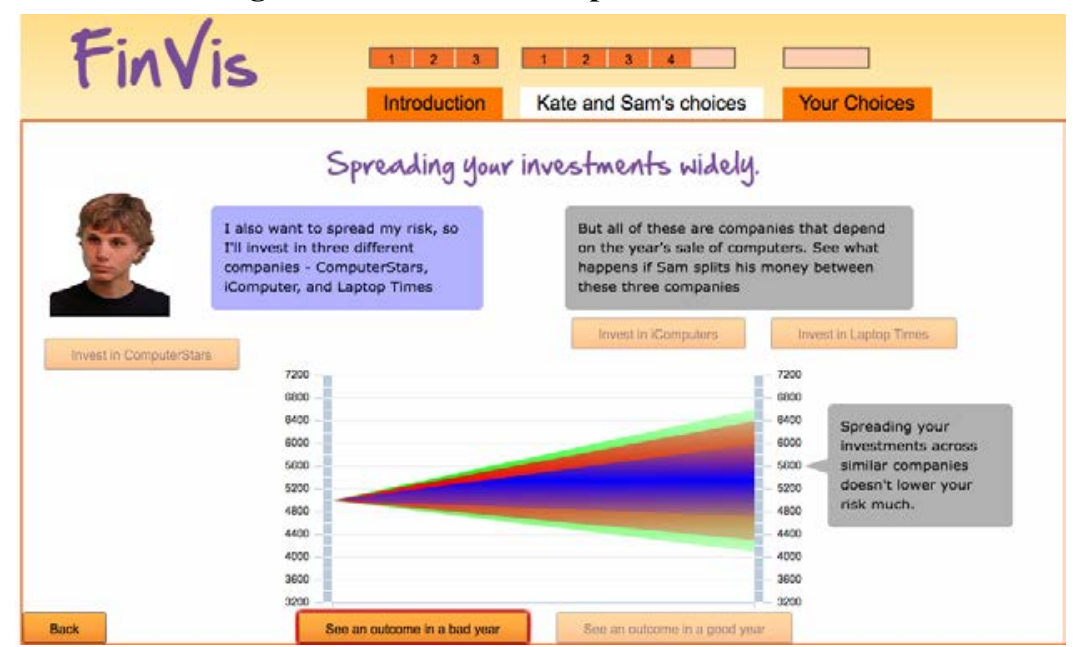

The user then proceeds to the interactive component (see Figure B3). The user is given 5 minutes to allocate $\$ 5,000$ hypothetical dollars to his/her portfolio. The funds and stocks from the tutorial are possible options for the user, and the user can add, modify and remove the funds and stocks and watch the risk cone update in real time. The tool tracks all user actions, and also records the final choice that the user made.

Figure B3: Interactive Component

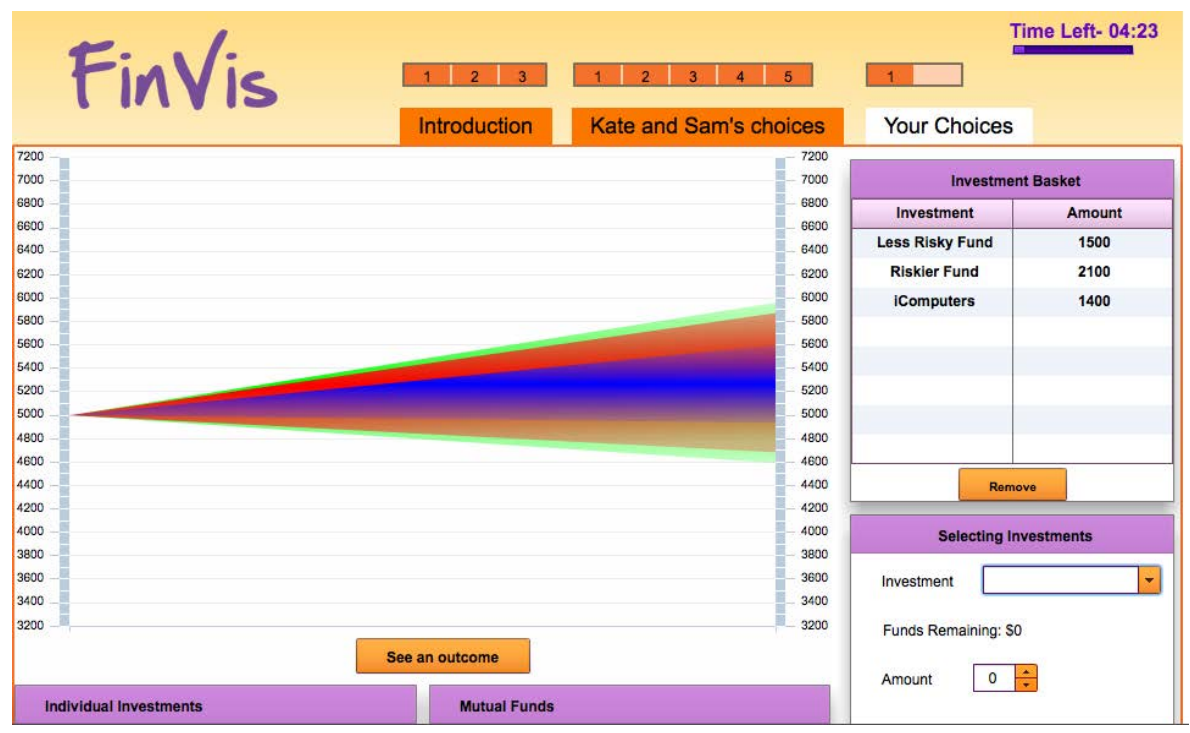

After the user is finished making his/her allocation choices, or after the 5 minutes has run out, the user proceeds to the outcome screen. The outcome screen provides feedback to the user about several key concepts. First, the user receives feedback about whether he/she invested in all stocks, all funds, or a combination. Users who invested in funds are congratulated on greater diversification. Users who invested only in stocks receive the suggestion that investing in funds can lead to greater diversification. Then users are informed that they took on some risk - and receive feedback in the form of a list of the lowest and highest bound numbers for the risk cone. Because individuals have different risk preferences, the guidance offered is simply to ask the user to reflect on whether this is a suitable risk profile for him/her.

As in Kroll, Levy, and Rapoport (1988), we generated artificial risk and return profiles for each stock and fund, which are summarized in Appendix B. 


\section{"Mutual Funds"}

\begin{tabular}{|l|l|l|}
\hline Fund Name & $\begin{array}{l}\text { Annual Percentage } \\
\text { Rate (APR) }\end{array}$ & Standard Deviation \\
\hline Stable Fund (A) & $3 \%$ & $3 \%$ \\
\hline Aggressive Fund (B) & $7 \%$ & $12 \%$ \\
\hline
\end{tabular}

"Stocks"

\begin{tabular}{|l|l|l|}
\hline Stock Name & $\begin{array}{l}\text { Annual Percentage } \\
\text { Rate (APR) }\end{array}$ & Standard Deviation \\
\hline ComputerStars (C1) & $7 \%$ & $13 \%$ \\
\hline iComputers (C2) & $6 \%$ & $12 \%$ \\
\hline LaptopTimes (C3) & $8 \%$ & $14 \%$ \\
\hline CornWorld (D1) & $4 \%$ & $4 \%$ \\
\hline OhLaLa (D2) & $5 \%$ & $7 \%$ \\
\hline
\end{tabular}

\section{Correlation Matrices}

\begin{tabular}{|l|l|l|l|l|l|l|l|}
\hline & A & B & C1 & C2 & C3 & D1 & D2 \\
\hline A (Stable Fund) & 1 & & & & & & \\
\hline B (Aggressive Fund) & 0.5 & 1 & & & & & \\
\hline C1 (ComputerStars) & 0.8 & 0 & 1 & & & & \\
\hline C2 (iComputers) & 0.8 & 0 & 0.9 & 1 & & & \\
\hline C3 (LaptopTimes) & 0.8 & 0 & 0.9 & 0.9 & 1 & & \\
\hline D1 (CornWorld) & 0 & 0.8 & -0.8 & -0.8 & -0.8 & 1 & \\
\hline D2 (Ohlala) & 0 & 0.8 & -0.5 & -0.5 & -0.5 & -0.5 & 1 \\
\hline
\end{tabular}




\section{Figure B4: Brochure}

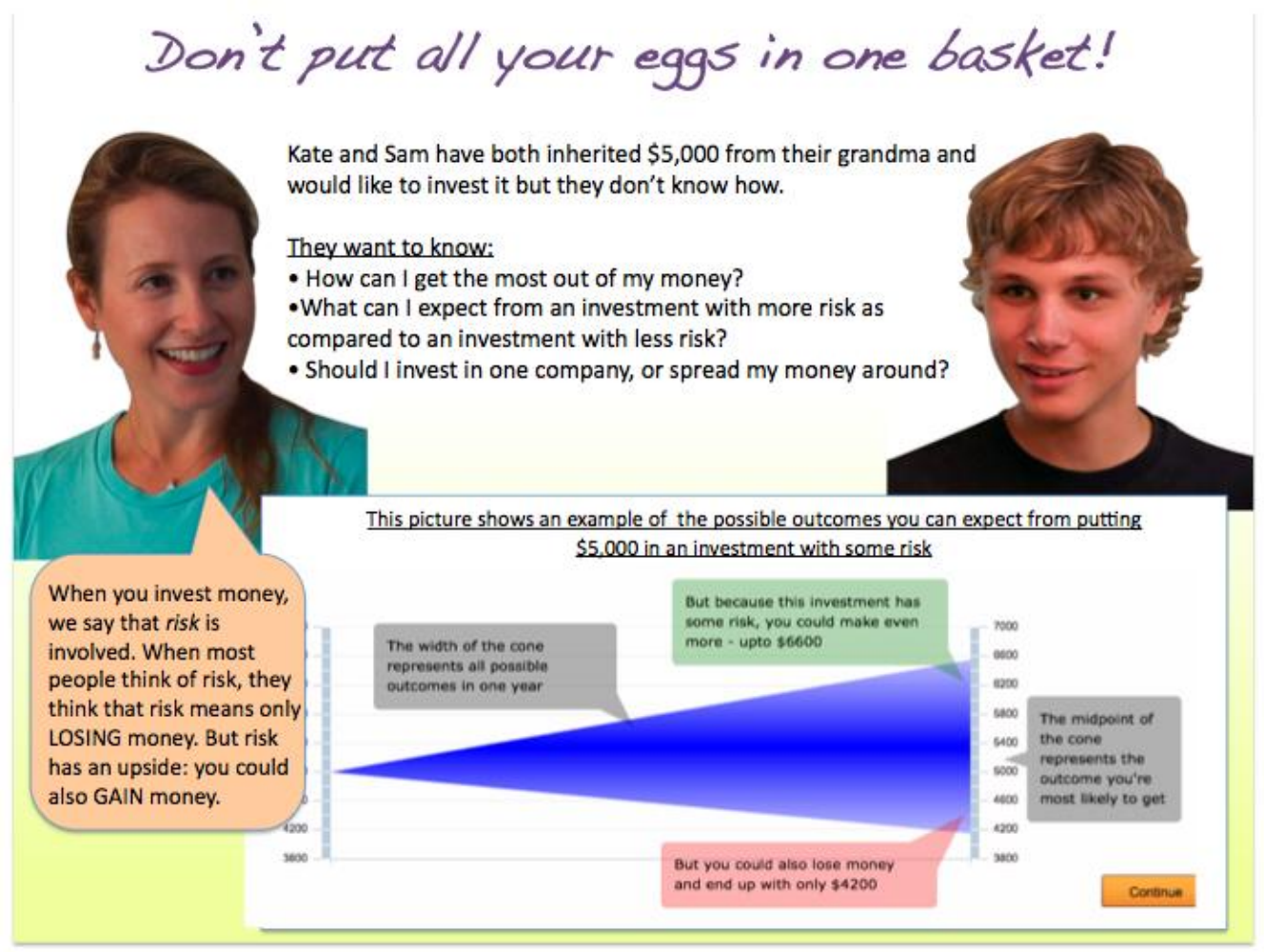

\section{What can we expect from different investments?}

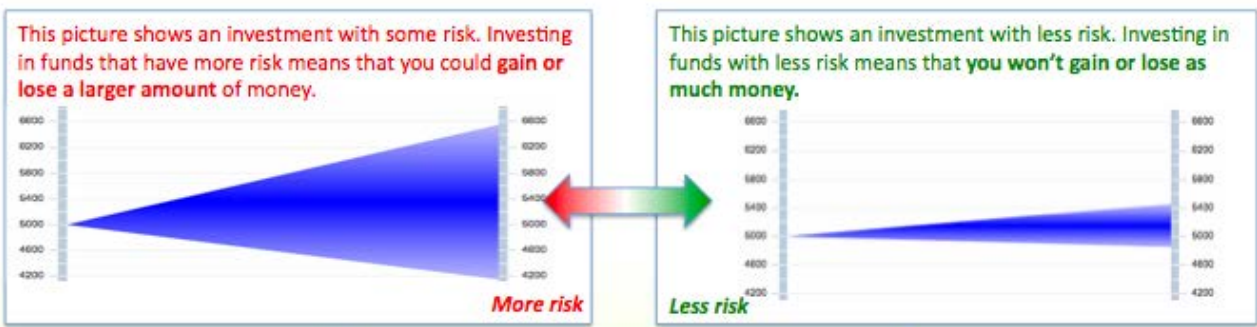

An investment may gain or lose a lot of money over a short period of time, like days or months, but over a longer period of time, the gains and losses will even out and one can expect the most likely outcome, represented by the midpoint of the cone.

It's like flipping a coin - you expect it to land on "heads" hali the time, but if you flip it only 3 times, it could land on "heads" all three times. But if you flip it 300 times, you are much more likely to get "heads" about half the time.

\section{How can you avoid losing everything} from year to year?

$\checkmark$ Spreading your investments out, like investing in many very different companies, will lower the overall risk you take on..

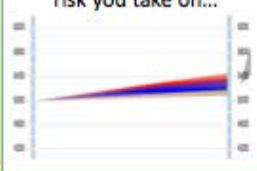

$X$...but spreading your investments across similar companies doesn't lower your risk much.

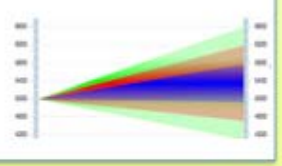

It's hard to know all the companies that exist, so investing in "Funds", is a good way to spread investments widely - they're already made up of lots of different companies.

But funds can also consist of many of the same companies, so make sure you invest in different types of funds too, like a U.S. fund and an international fund. 


\section{Appendix C: ALP Sampling Procedures}

ALP respondents have been recruited in one of four ways. Most were recruited from among individuals age $18+$ who were respondents to the Monthly Survey (MS) of the University of Michigan's Survey Research Center (SRC). A subset of respondents (approximately 500) were recruited through a snowball sample; here respondents were given the opportunity to suggest friends or acquaintances who might also want to participate. Respondents without Internet (both in the Michigan sample and the snowball respondents) were provided with so-called WebTVs (http://www.webtv.com/pc/), which allows them to access the Internet using their television and a telephone line. The technology allows respondents who did not have previous Internet access to participate in the panel and furthermore use the WebTVs for browsing the Internet or use email. A new group of respondents (approximately 500) has recently been recruited after participating in the National Survey Project, created at Stanford University with SRBI. This sample was recruited in person, and at the end of their one-year participation, they were asked whether they were interested in joining the ALP. Most of these respondents were given a laptop and broadband Internet access. Finally, in recent years, recruiting of panel members is based on Address Based Sampling (ABS), where once again potential respondents are given a laptop to allow them to participate if they don't have Internet access yet. For more information about the ALP sample recruiting methodology as well as access to the data collected in the ALP to date, the reader is referred to http://mmic.rand.org

\section{Appendix D: Questionnaire}

6. If I need to make an investment decision, I can select a mix of investments that are in line with how much risk I want to take on.

f. Not at all true

g. Hardly true

h. Moderately true

i. Exactly true

7. In general, investments that are riskier tend to provide higher returns over time than investments with less risk.
j. True
k. False
1. Don't know

8. Which of the following is an accurate statement about investment returns?

m. Usually, investing $\$ 5,000$ in shares of a single company is safer than investing $\$ 5,000$ in a fund which invests in shares of many companies in different industries

n. Usually, investing $\$ 5,000$ in shares of a single company is less safe than investing $\$ 5,000$ in a fund which invests in shares of many companies in different industries

o. Usually, investing $\$ 5,000$ in shares of a single company is equally as safe as investing $\$ 5,000$ in a fund which invests in shares of many companies in different industries.

p. Don't know

9. Suppose you are a member of a stock investment club. This year, the club has about $\$ 200,000$ to invest in stocks and the members prefer not to take a lot of risk. Which of the following strategies would you recommend to your fellow members?

q. Put all of the money in one stock 
r. Put all of the money in two stocks

s. Put all of the money in a stock indexed fund that tracks the behavior of 500 large firms in the United States

t. Don't know

10. How confident are you that you have a grasp of how risk changes when choosing a different mix of investments?
u. Extremely confident
v. Very confident
w. Somewhat confident
x. Not very confident
y. Not at all confident 